\title{
Analysis of the Implementation of Internal Quality Assurance System in Private Islamic High Schools in Mataram-Lombok
}

\author{
Sudirman Wilian*, Dadi Setiadi, Nyoman Sridana \\ Department of Educational Administration \\ Mataram University \\ Lombok, Indonesia \\ *sudirman_wilian@unram.ac.id, setiarasyid@gmail.com, sridana60@gmail.com
}

\begin{abstract}
The internal quality assurance system (IQAS) of the secondary education unit is a quality assurance system which involves all components in the education unit. However, IQAS seemed to be scarcely heard in many private schools, including that of the Islamic private high schools in Mataram - West Nusa Tenggara Province, Indonesia. The purpose of this research is to find out to what extent do teaching staffs, school principals, and other members of the education unit understand and apply the IQAS in their schools so that the quality of the process as well as the learning outcomes of the students could be equivalent with what have been established at public schools. Using qualitative descriptive method, data were collected through document, questionnaires, and interviews with teachers, principals, and supporting education unit staffs. The results of the study claimed that the teaching staff and education unit as a whole did not fully understand the IQAS of the secondary education unit. IQAS programs were not well organized to meet the national education standards. All school members did neither have a good understanding of IQAS nor a good quality assurance team. Consequently, school programs did not lead to gradual quality improvement to achieve or even exceed the national education standards.
\end{abstract}

Keywords: education quality assurance, internal quality assurance system, secondary education unit, national education standards

\section{INTRODUCTION}

The internal quality assurance system is a quality assurance system carried out in and by certain education units which involve all components in the education unit. Nationally, the quality of secondary education in Indonesia does not perform as expected. The results of national education quality mapping show that only about $16 \%$ of education units meet the national education standards [1].

The secondary education quality assurance system is an elemental unity consisting of policies and processes referring to the implementation of education quality assurance carried out by each secondary education unit to ensure the realization of qualified education that meets or exceeds the national education standards. The education unit must implement education quality assurance properly, independently, and sustainably. According to the National Education System Act No. 20 of 2003, the national education system is an overall component of education that is interrelated in an integrated manner to achieve national education goals. Each education unit is required to carry out an education quality assurance in the attempt to meet or exceed the national education standard. To be able to carry out the education quality assurance, the education unit must be able to establish internal quality assurance system (IQAS), the purpose of which is "to develop a quality culture within the school and to implement a strategy for the continuous improvement of quality" [2].

However, most secondary education units in Indonesia and especially in West Nusa Tenggara Province, have not yet had the ability to assure that all processes implemented meet the quality standards.

Therefore, this study is worth conducted to be able to find out to what extent do the management team of private schools (principals, teachers, administrative staffs) as an organization unit in the city of Mataram understand and implement the internal quality assurance system (IQAS) as well as the quality assurance system planning programs by which the national education standard could be achieved. It is expected that the results of the study could be used to inform the related agents under the departement of national education and culture which subordinate and supervise the school units as the basis for the preparation or development of quality programs in the education unit.

\section{MethodS}

This research used a descriptive qualitative approach as the research design. The object of research were the two private Islamic high schools in Mataram, namely Muhammadiyah High School and Nahdatul Wathan (NW) High School with all teachers, school principals as well as administrative staffs as population. Data were collected through document, questionnaires, and interview while sources of data were all the permanently employed teacher's administrative staffs, and the two principals. The research instruments used were 
questionnaires, interview guides, and document analysis guidelines. Questions asked in the instruments cover such understanding of the respondents as national education standards coverage, internal quality assurance system, internal self-evaluation of the school, etc. Data were analysed and interpreted qualitatively following the stages: data collection, data reduction, classification, and calculation from the questionnaire data. The information collected from all the three types of data collection were the principals', the teachers' as well as the teaching staffs' general understanding on IQAS, along with its concept, principles, objectives, scopes, and cycles in mapping educational quality.

\section{RESULTS AND DISCUSSION}

From the data on Table 1, in which the score of all the school management team's comprehension on IQAS were measured using Likert's five scale in the questionnaire, it shows that the school principals, teachers, and administrative staffs understanding of IQAS was low or below an acceptable level, the score consecutively revealed 2.20, 2.13, and 2.85. The administrative staffs score was higher than both the teachers and the principals. On average, the three-element school score was only 2.39 , which is also still low. This means that teachers and administrative staffs did not understand well about the concepts and principles, objectives and scope of the IQAS of the education unit.

TABLE I. TEACHERS', PRINCIPALS', AND ADMINISTRATIVE STAFFS' UNDERSTANDING OF IQAS

\begin{tabular}{|l|l|l|l|}
\hline & \multicolumn{1}{|c|}{ Management Team } & \multicolumn{1}{|c|}{ Score* } & Category \\
\hline 1. & School principals & 2.20 & Low \\
\hline 2. & Teachers & 2.13 & Low \\
\hline 3. & Administrative staffs & 2.85 & Low \\
\hline & Average & 2.39 & Low \\
\hline
\end{tabular}

*Score range: 1 - 5 (1=very low, 2=low, 3=adequate, 4=good, $5=$ =ery good)

Basic understanding of IQAS is important for the implementers of internal quality assurance because lack of knowledge about IQAS will lead to incapability to carry out IQAS properly in the best way. The solution, as proposed by Lamosi and Mukonyi [3] was that principals should be able to strengthen the management of alternative qualities such as, teacher appraisal, use of internal quality assurance by capacity building on requisite knowledge and skills.

Basically IQAS relates to the 8 National Education Standards (NES) and the teacher's tasks are to establish connection especially to the standards of graduate competence, content standards, process standards, evaluation standards, as well as educator standards themselves. As to the extends of the teachers' understanding on these four NES elements, as shown in Table 2, it was found that the level of understanding of the educators on the standards of graduate competence score is 3.04, standard of content is of 3.6, process standard by 3.0, and standard of evaluation is 3.43 . On average, the standard is 3.26 , which means that their comprehension is good enough. Additionally, the score of any relatable issues of standard of teaching staff reached a score of 3.8. This understanding has only attained a sufficient level but for the standard of teaching staff was close to good category. However, to be able to implement the process and evaluation in accordance with the standards, the level of understanding of the educators must be good. Furthermore, teachers are accepted based on the knowledge of curriculum content and professional qualifications that have been set by the government [4].

TABLE II. THE LEVEL OF TEACHING STAFFs' COMPREHENSION ON 4 NES COMPONENTS

\begin{tabular}{|l|l|c|c|}
\hline & \multicolumn{1}{|c|}{ Names of Standard } & Score & Category \\
\hline 1. & Graduate competence & 3.04 & Adequate \\
\hline 2. & Content & 3.6 & Adequate \\
\hline 3. & Process & 3.00 & Adequate \\
\hline 4. & Evaluation Average & 3.43 & Adequate \\
\hline & \multicolumn{2}{|c|}{3.26} & Adequate \\
\hline
\end{tabular}

*Score range: $1-5$ (1=very low, 2=low, 3=adequate, 4=good, 5=very good

Regarding the implementation of IQAS in schools chosen for the purpose of the study, the IQAS cycle consists of 5 stages. First, mapping the quality of education carried out by educational units based on the National Education Standards. The administrative staffs and school educators did not have proper understanding about the stages of education quality planning starting from the preparation of instruments, data collection, and analysis of the mapping data results that would be related to the making of plans for the next stage of the IQAS cycle. Activities at this stage are in the internal evaluation stage, which can be carried out by stages of Plan, Do, Check and Act [5].

Second, making a quality improvement plan as outlined in the School Work Plan, the school did not know how to make quality improvement plans related to national education standards. The making of school plans related to quality improvement must be prepared based on school self-portraits of quality conditions during self-evaluations that was carried out, then compiling a number of work plans that were overall oriented towards improving the quality of administrative and learning processes.

Third, the implementation of quality fulfilment both in the management of the education unit and the learning process, the management of the education unit has not thoroughly been understood at either stage of the IQAS cycle. This referred to the level of understanding of the previous stage. Therefore, indepth study related to the implementation of IQAS for the fulfilment of quality in the management of education units and the learning process widely was an urge to conduct. This requires the unity of all school members to cooperatively implement school programs related to the fulfilment of education quality according to standards.

Next is monitoring and evaluating the implementation process of quality fulfilment that has been carried out. At this stage, the school still required good knowledge regarding the role and function of monitoring and evaluation for each quality fulfilment program that it will be useful for the next process of preparing new standards and strategies for achieving the quality that has been planned. 
In the context of the implementation of internal quality assurance, program determination and implementation, through a predetermined mechanism [9], only a small portion of teachers understand the stages of implementing quality assurance system as follows: plan, do, and carry out evaluation (evaluation) stages, on an ongoing basis.

\section{CONCLUSIONS}

The level of knowledge of the school members related to IQAS was at a low level which remain in urgent need to be developed before establishing the education unit of internal quality assurance system. However, the understanding of the educators regarding the national education standards (NES) that are closely related to their duties was still at a sufficient level that the increase of understanding is encouraged in order to carry out the process and evaluation in accordance with the standards. It is necessary that educators and the education staffs develop their knowledge and skills in the implementation of internal quality assurance through a special team from external education units until the school is ready to implement the internal quality assurance system.

It is suggested, however, that the support from the government should be continued to provide adequate infrastructures and facilities in the schools to create a conducive teaching and learning environment for both teachers and students [10], intensified and possibly private participation in the practice should be encouraged [11]. The systems of quality control with regard to the actors, i.e. the stakeholders instead of the institutional configurations: (1) state control and accountability by bureaucratic means and legal regulations, (2) professional control and accountability, and (3) consumer control and accountability [12] are also required. Moreover, it is significant to have the support of adequate facilities and equitable educators that will have a significant impact on the implementation of the internal quality assurance system in schools [13]. Also, to further improve quality assurance in conjunction with the learning process, students expressed high satisfaction with the state of learning resources and the competence of the academic staff available to them [14] and must focus on economical, technical, and organizational dimensions as main dimensions of feasibility system [15].

\section{REFERENCES}

[1] Directorate General of Primary and Secondary Education, Indonesian Ministery of Education and Culture, Petunjuk Pelaksanaan Penjaminan Mutu Oleh Satuan Pendidikan. Jakarta. 2016.

[2] P. Praraksa, S. Sroinam, M. Inthusamith and M. Pawarinyanon, "Model of Factors Influencing Internal Quality Assurance Operational Effectiveness of the Small Sized Primary Schools in Northeast Thailand", Social and Behavioral Sciences vol. 197, pp. $1586-1590$, 2015 .

[3] B. A. Lumosi and P. W. Mukonyi, "Quality Monitoring in Secondary Education in Kenya: A Comparative Analysis of Public Schools in Kakamega East and Kakamega Central Sub-Counties of Kakamega County". International Journal of Education and Research, vol. 3, no. 1, 2015 .

[4] N. Onuma and N. P. Okpalanze, "Assessment of Quality Assurance Practices in Secondary Schools in Enugu State Nigeria", Middle-East Journal of Scientific Research, vol. 25, no. 8, pp. 1695-1714, 2017. 
[11] S. Joseph and A. Adetayo, "Quality Assurance and Effectiveness of Lagos State Junior Secondary Schools". 2012.

[5] R. Nelson, M. Ehren and D. Godfrey, "Literature Review on Internal Evaluation", London: Institute of Education, 2015.

[6] S. O. Adegbesan, "Establishing Quality Assurance in Nigerian Education system: Implication for Educational Managers. Educational Research and Reviews, vol. 6, no. 2, pp.147-151, 2011.

[7] C. Caesar, "Framework for Delivery of Quality Education: Examination of quality concepts to inform a framework for improving education quality in St Lucia a member of the Organization of Eastern Caribbean states (OECS)”. American Academic \& Scholarly Research Journal, vol. 5 , no. 1,2013

[8] K. Almadani, N. Reid, S. Rodrigues, "Quality Assurance: A Pressing Problem For Education in the $21^{\text {st }}$ Century", Problems of Education in the $21^{\text {st }}$ Century. vol. 32 , pp. 9-21. 2011.

[9] S. Uchtiawati and I. Zawawi, "Penerapan Penjaminan Mutu Pendidikan pada Sekolah Menengah Atas berstandar Internasional". Jurnal Kebijakan dan Pengembangan Pendidikan, vol. 2, no. 1, 52-56, 2014.

[10] B.K. Oyewole, "Repositioning Secondary School Administration for Quality Assurance in Ekiti State, Nigeria", Journal of Management and Sustainability, vol. 3, no. 3, 2013.
[12] S.G. Huber and B. Gördel, "Ouality Assurance in the German School System", European Education Research Journal, vol. 5, no. 3, pp. 196209, 2006.

[13] Darman, Darwin, Yusnadi, "Implication of Internal Quality Assurance System of Schools Implementation Against the Accreditation rating of State Senior High Schools of Natuna, Riau Island Province", Journal of Research \& Method in Education, vol. 7, no. 5, pp. 36-39, 2017.

[14] H.B. Essel1, M. Boakye-Yiadom and F.A. Kyeremeh, "Assessing Students' Experiences of Internal Quality Assurance Practices in Selected Private Higher Education Institutions”. Int. J. Sci. Res. vol. 7, no. $1,2018$.

[15] F. Amir, "Developing Structure for Management of Quality in Schools: Steps towards Quality Assurance Systems". American Journal of Education Research, vol. 3, no. 8, pp. 977-981, 2015. 